\title{
Haderen, elskeren og læseren: Holdning, underholdning og pædagogisk potentiale i essayistisk skrivelitteratur
}

\author{
AF CHRISTINE ISAGER
}

\section{Abstract}

I en sammenlignende læsning af to markante eksempler på essayistisk skrivning om skrivning, Ole Meisners "Haderen" (2008) og Stanley Fishs How To Write a Sentence and How to Read One (2011), udpeges styrker og svagheder ved underholdende og holdningspræget håndbogsretorik. Formen kan engagere urutinerede skribenter, heriblandt journaliststuderende, og styrke deres sprogfaglige selvforståelse. Den ironiske humor hos Meisner synes imidlertid at undergrave dette ærinde ved at fokusere på fejltrin og ufrivilligt komisk sprogbrug. Fishs fokus på bevidst efterligning af gode eksempler synes i højere grad at bemyndige læserne og anvise et videre skrivepædagogisk potentiale.

"Ord kan du roligt hade", skriver sprogkonsulent Ole Meisner som indledning til et centralt kapitel i lærebogen Godt dansk (Skyum-Nielsen, red., 2008: 140). Bogen henvender sig ifølge bagsideteksten til "enhver, der ønsker - professionelt eller personligt - at blive bedre til at tale og skrive dansk", og i praksis hører en hel del journaliststuderende til bogens publikum. Meisners kapitel, der tidligere har været udgivet som selvstændigt hæfte (Meisner, 2004), vækker allerede i indholdsfortegnelsen opmærksomhed med sin titel: "Haderen”. Hvor de øvrige kapiteloverskrifter nemlig refererer til velkendte tekstlige enheder eller sproglige kvaliteter (fx "Sætningen”, "Ordvalget”, "Vellyden”), kan "Haderen" forstås på to måder: enten adjektivisk som reference i 
tidstypisk ungdomsjargon (se Hartling, 2012) til selve den upassende og dermed foragtelige ("haderen") kvalitet af den sprogbrug, der behandles i kapitlet, eller som en reference til skribenten selv ("haderen"), der med et glimt i øjet inviterer læseren til at dele sit kritiske perspektiv på offentlig sprogbrug.

Det fællesskab og den ironiske humor, der appelleres til, har en lang tradition i journalistisk kontekst, hvor "sprogbøffer" fra medierne gerne udstilles og kommenteres i faste bagsidespalter som eksempelvis Weekendavisens "Sandt at sige" eller Politikens "Oh Danmark!". Sidstnævnte "hælder ...", som avisen selv har formuleret det, "... ugens kvajeri i pressen ud til almindelig beskuelse på Bagsiden, sådan som rubrikken har gjort i årevis". ${ }^{1}$ I lignende stil og tone mobiliserede Politikens bagsideredaktion i 2014 ca. 7.200 "ækelordshadere" blandt læserne til at deltage i en afstemning blandt "sprogets værste fejltrin". ${ }^{2}$ Formen findes også på dagbladenes debatsider, hvor fx kronikskribenter ironiserer over ubehjælpsomt mediesprog, ${ }^{3}$ og desuden dyrkes den i regi af sociale medier, fx Facebook-grupper med navne som "Jeg dømmer dig, når du staver forkert!", "Sprogpolitiet" og "Dagens sprogsinke". ${ }^{4}$ Disse populære formater har en række retoriske karakteristika til fælles med Ole Meisners ironiserende fremstilling, som kan være problematiske i lige præcis en skrivepædagogisk kontekst. Når "Haderen" sætter fokus på at dadle dårlig sprogbrug, bliver det egentlige emne, principper for god sprogbrug, nemlig fremstillet som ikke bare komplekst, men uhåndterligt og uoverskueligt. Og uoverskueligheden dyrkes i både struktur og stil som en grundbetingelse for tekstens særlige humor, hvilket jeg vil uddybe nærmere i en nærlæsning nedenfor.

Dernæst vil jeg præsentere en direkte alternativ, værdsættende sprogholdning, der her er repræsenteret ved den amerikanske litterat Stanley Fish. I sin populære, essayistiske håndbog How To Write a Sentence and How To Read One fra 2011 appellerer han dels til, at man læser andre skribenters tekster for at aflure virkningsfulde sætningsstrukturer, dels at man selv prøver disse strukturer af som en form for sproglige kampsportsøvelser. Fish lægger sig på den måde i den klassisk retorikpædagogiske imitatio- eller efterligningstradition, der knytter skrivning tæt til læsning efter det princip, at nærstudier af andres retoriske håndværk kan komme nærlæserens egen retoriske praksis til gode 
(se fx Harsting, 2001; Quintilianus, 2001; Andersen, 1995; Kock, 2013; Isager og Sigrell (red.), 2015). Fishs retorik er altså grundlæggende fokuseret på at fejre god sprogbrug ved at imitere den, og i kraft af bogens struktur og stil fremstilles principperne for god sprogbrug som komplekse, men ikke desto mindre tilgcengelige og håndterbare. Fishs fremstillingsform tjener således i højere grad det formål, som Meisner og Fish har til fælles, nemlig at indlemme og engagere mere urutinerede sprogbrugere i et fællesskab af selvberoende og reflekterede skribenter.

Før jeg tager fat på analysen, vil jeg gøre rede for min tilgang til stoffet og for den særlige essayistiske skriveform, de to tekster repræsenterer.

\section{Hvorfor nærlæse netop Meisner og Fish}

I denne tværfaglige sammenhæng er det på sin plads at præcisere, at min læsning af de to tekster hører til i den forskningstradition, der kaldes retorisk kritik (se fx Villadsen, 2009; Lund og Roer (red.), 2014). På grundlag af en nærlæsning, der fremhæver konkrete træk ved teksten, argumenterer jeg for en bestemt fortolkning og vurdering af teksternes retoriske funktioner. Præmissen for en sådan nærlæsning er, at en teksts ide, indhold, argumentation, struktur og stil vil (hvad enten det er tilsigtet eller utilsigtet) afspejle skribentens opfattelse af sin kommunikationssituation, herunder opfattelsen af publikums normer og værdier. Dermed antages konkrete træk ved teksten også i bredere forstand at afspejle normer og værdier i et bestemt miljø og en bestemt social eller kulturel kontekst, som kan være værd at eksplicitere og diskutere.

Mit valg af de to konkrete tekster er som udgangspunkt genremæssigt motiveret. Jeg ønsker med min nærlæsning at skabe kritisk opmærksomhed omkring, hvad man kan betegne som den charmerende del af skrivelitteraturen, nemlig den, der har essayistisk og dermed både holdnings- og underholdningspræg. I en gennemgang fra 1998 af et bredt udvalg af nordisk litteratur om skrivning inddeler norske Jo Bech-Karlsen 27 forskellige udgivelser i følgende tre hovedkategorier: 1) regelbøger, der primært omfatter "håndbøker med tommelfingerregler", 2) teoribø- 
ger i form af lærebogs- og akademisk litteratur, der begrunder, hvorfor vi skriver, som vi skriver, og endelig 3) inspirationsbøger, der blandt andet omfatter "[f]orfatteres con amore-skildringer av skrivingens mysterier" (Bech-Karlsen, 1998: 91). Bech-Karlsen betegner selv dette som en grov inddeling (91), men formaterne er umiddelbart genkendelige, både i deres rene former og i overlappende udgaver. Analysematerialet i denne artikel, Meisners "Haderen" og Fishs How To Write a Sentence, er interessante, fordi de er udformet som en blanding af kategori 1 og 3: Teksterne vil anvise, hvordan man kan skrive godt (eller i Meisners tilfælde især hvordan ikke), men ærindet er i lige så høj grad at inspirere læseren til at både skrive og læse opmærksomt og interessere sig for sprogbrug i det hele taget. Begge skribenter skriver åbenlyst con amore, som Bech-Karlsen udtrykker det, dvs. med kærlighed til stoffet, og deres individuelle personlighed, der er understøttet af en personlig, holdningspræget skrivestil, udgør en tydelig og væsentlig del af teksternes appelform. I forhold til en klassisk lærebog i kategori 1, hvor en asymmetrisk og relativt upersonlig relation mellem en vidende fagperson og dennes læsere er naturlig, giver kombinationen med kategori 3 i disse tekster et langt tydeligere fokus på, at relationen er både faglig og social og gerne skal blive symmetrisk.

Leif Becker Jensen har i Journalistica 1 fra 2013 tematiseret netop socialiseringsprocesser i den journalistiske sprogkultur. Med et velkendt negativt påbud - undgå passivformer! - som illustrativt eksempel peger Becker Jensen på en uhensigtsmæssig normativ sprogkultur blandt journalister, hvor påbud som disse "internaliseres som "mavefornemmelser"” (141) og bliver til dogmer i en konservativ mesterlæretradition, der afspejler sig i et flertal af de lærebøger, der bruges på de danske journalistuddannelser (144-6). Becker Jensen slår i stedet et slag for en funktionalistisk tilgang, der tilsiger, at eksempelvis en passiv form af et verbum fint ville kunne overvejes og vælges "ud fra konteksten og formålet med kommunikationen” (155; se også Kock, 2007). Dette lyder ikke umiddelbart kontroversielt, men faktisk præsenterer Becker Jensen det som et reelt pædagogisk dilemma, at man som sprogunderviser ved akademiske journalistuddannelser forventes at være relativt kategorisk og generaliserende på håndværkstraditionens præmisser - idet de studerende jo skal 
kunne "gebærde sig i branchen" (168) - og samtidig analytisk og kritisk på universitetskulturens præmisser - idet man problematiserer normerne og lader de studerende "opdage andre muligheder" (168) i form af sproglige og stilistiske alternativer, der "overskrider den tavse viden" (146). Afslutningsvis skriver Becker Jensen, at han i sin pædagogiske praksis vælger at tilgodese begge traditioner ved først at videreformidle de traditionelle råd og normer og så sidenhen problematisere dem. Dette er tilsyneladende almindelig praksis, også selvom fremgangsmåden selvfølgelig, som Becker Jensen faktisk siger det, indebærer den risiko, at "normerne når at sætte sig så meget på rygmarven [hos den journaliststuderende], at de ikke længere kan problematiseres” (169). Det er en skuffende statusmelding at få i en artikel, der samtidig så overbevisende påviser, hvordan den normative sprogkultur appellerer ikke bare til sproglig konformitet, men til en grundlæggende uhensigtsmæssig forståelse af sprog og stil som noget, der kan vurderes uafhængigt af konteksten og det kommunikative formål.

I min analyse vil jeg gerne tage tråden op og vise, at den socialiserende impuls vitterligt kan være stærk i den essayistisk prægede skrivelitteratur og dertilhørende sprogkultur, og at dette ikke behøver at stå i modsætning til en udogmatisk og funktionelt orienteret sprogforståelse. Som udgangspunkt er det jo nemlig ikke problematisk at efterstræbe et relativt symmetrisk forhold til sin læser, som både Meisner og Fish gør det. Den ambition er typisk for den causerende eller essayistiske stil, de vælger, og et nærmere blik på essaygenren, som den er behandlet i Graham Goods The Observing Self fra 1988, kan være med til at kaste lys over den særlige læserrelation. Good karakteriserer essayistens rolle og autoritet som beroende på skribentens erfaring snarere end på formel uddannelse og ekspertise. Essayisten kan meget vel være højtuddannet og fortrolig med magtfulde institutioner i samfundet, men den position, der skrives fra, er i essayet typisk løsrevet fra institutionel sammenhæng. Essayisten, hedder det, "is rooted in society ... but still has a detached, skeptical view of his environment" (10). Synsvinklen er bevidst placeret på sidelinjen, præget af ro, overblik og kritisk eller skeptisk distance, og tonen er dannet, men kan gennem hele essaytraditionen også karakteriseres som venskabelig (13). 
Denne uafhængighed og venskabelighed er igen tæt forbundet med det videnssyn, essayet repræsenterer: Essayet er ikke optaget af systemer, "the grand design and the major truth", men af små observationer, små sandheder, der er personlige og foreløbige (Good, 1988: 4). Formelt afspejler dette sig i en tilsyneladende spontan og usystematisk stil, der dog sagtens kan være resultatet af omhyggelig, litterær forarbejdning. Teksten vil være lagt til rette, så den i modsætning til en videnskabelig artikel ikke egner sig til at blive citeret, opsummeret og bygget videre på, hedder det, idet skribentens holdning og relation til sit emne markeres som enestående og foreløbig: "[S]elf and object organize each other, but only in a temporary way. Nothing can be built on this configuration, no rules or methods deduced from it" (4). Essayistisk viden har i denne forstand æstetisk karakter. Essayet videregiver ikke gennemprøvede ræsonnementer eller konklusioner, men udgør et selvstændigt tankeunivers, der i kraft af selve læseoplevelsen kan være til inspiration for sit publikum og anvise en mulig måde at reflektere over et givent emne på. Dette formuleres også klart hos Elisabeth Hoff-Clausen i hendes karakteristik af blogging som "online hverdagsessayistik":

Essayisten forventes ikke nødvendigvis at nå til et resultat eller en afsluttet erkendelse, men at reflektere på så interessant, tankevækkende og velformuleret en vis, at andre måtte ønske at følge med på essayistens vandringer i det stof, der måtte have fanget hendes eller hans interesse (se fx Sanderson, 1975; Grepstad, 1997; Greene-Gantzberg \& Mitchell, 1997). Essayisten forventes altså ikke at sidde inde med sandheden eller på systematisk vis at søge den, men at yde sin læser godt selskab og tankevækkende indsigt baseret på den enkeltes erfaring med verden.

Essayet skrives og læses ikke af pligt, men af lyst, og det helt afgørende er dermed, om essayisten er en person, man ønsker at være i selskab med. (2008: 142, fremhævelse origina/5)

Meisner og Fish positionerer sig klart, som vi vil se, uden for Bech-Karlsens kategori 2-format, hvor (ekspliciteret) teori og faglig terminologi formodes at kunne fremmedgøre læseren over for stoffet og skribenten. I stedet anlægges i teksterne, hvad man 
i bogstavelig og positiv forstand kan kalde en amatøragtig holdning med henvisning til ordets rod i det latinske amare, at elske - jf. igen Bech-Karlsens brug af betegnelsen con amore. Skribenterne stiller sig på læsernes side og appellerer til en fælles fascination af skriftsprog.

Lærebogsforfatteres valg af en relativt indforstået, common sense-baseret formidlingsstil kan godt skyldes manglende sprogfaglige forudsætninger for at begrunde de forskellige skriveråd, som Becker Jensen påpeger (2013, 155-6). I artiklen her vil jeg ikke desto mindre behandle den uhøjtidelige, slagfærdige stil i de pågældende tekster som et formvalg, der træffes med vilje, og som kan træffes med god grund, hvis man er opmærksom på, at den umiddelbart sympatiske indstilling til både stoffet og læseren kan have uheldige, utilsigtede funktioner, som fx (jf. igen Becker Jensen) at faglig viden forbliver tavs og respektindgydende. Det kan nemlig godt være tilfældet i tekster, der ellers synes skrevet i en helt anden ånd med en relativt klar og personlig stemme. Som Roderick Hart argumenterer for, kan man i studiet af skribentroller med fordel være særligt opmærksom på personlige henvendelsesformer. Med brug af fx jeg-fortalte anekdoter gør man særligt krav på sine tilhøreres opmærksomhed: "[L]isteners' ears perk up ... [T] emporarily, at least, they are open to influence because identifying with one another is such a basic human instinct" (Hart, 1997: 225-6). Også skriveforskeren Peter Elbow, der i øvrigt er kendt for at værdsætte resonans og stemme i skrevne tekster, peger på et særligt behov for analytisk agtpågivenhed i mødet med tekster med en stærk stemme: "One of the main goals of schooling and literacy is to help students work out multiple meanings. We succeed best by pushing away interpretative pressure that comes from a strong voice" (2007, 11, min fremhævelse). En præmis for min læsning er altså, at den slagfærdige, venskabelige positur i den essayistiske håndbogslitteratur udøver et, med Elbows ord, markant fortolkningsmæssigt pres, der nemt kan overses, fordi henvendelsesformen er tiltalende, og faktisk er det pr. konvention: "The essay [as genre] presupposes ... a sympathetic reader" (Good, 1988: 4, min fremhævelse).

Det er ikke mindst dynamikken i denne præsupponerende form for læserhenvendelse, jeg vil se nærmere på i Ole Meisners 
kapitel, hvor skribentens betagede holdning til skriftsproget formidles på en retorisk set bagvendt facon, nemlig den ironiske.

\section{Meisner og de ironiske sprogrevseres fællesskab}

Hvor de to øvrige bidragydere til Godt dansk, Peder SkyumNielsen og Ebbe Grunwald, er sprogforskere, bidrager Ole Meisner (født 1944) til projektet på baggrund af sin lange karriere som journalist, kendt og prisbelønnet nyhedsoplæser hos Danmarks Radio og senere sprogkonsulent sammesteds. ${ }^{6}$ Denne forhåndsviden om skribenten skaber forventninger til form og indhold i hans kapitel om at være baseret på skribentens personlige overblik og erfaringer i kontrast til et mere akademisk perspektiv. Men derudover forventes bidraget at være præget af de standarder for sproglig og social korrekthed, som Meisner på DR's vegne repræsenterer. Valget af den ovennævnte kapiteloverskrift "Haderen" får dermed en klart ironisk og selvironisk effekt, idet den med ét ord signalerer, at tilgangen til stoffet vil være personlig, både humoristisk og holdningspræget, snarere end formel eller institutionel. Her tilbydes et fortroligt backstage perspektiv på korrektheden, som Meisner ved denne lejlighed på én gang vil repræsentere og holde lidt fri fra. Det er sidstnævnte dobbelthed i skribentrollen - en formel autoritet henvender sig uformelt - der kan udgøre en særlig fortolkningsmæssig udfordring for læseren.

Ironien fastholdes som stilistisk princip kapitlet igennem og er primært markeret ved brug af overdrevent negative og subjektive følelsesappeller. Indledningsvis lover Meisner sin læser at stille "et bredt udvalg af [sproglige] trivialiteter til skue, rent ud sagt til spot, skændsel og offentlig udhængning" (141). Han varsler, at "sidst i kapitlet ... finder du et register over hadeord, "Gabestokken"” (141), men før man når så langt, passerer man et afsnit betitlet "De ulidelige, de lumske og de værste" (154-59); læserne kan dukke sig for "Salver af fejlskud" (172-75) eller more sig over dem, ligesom de kan gyse eller godte sig, når det demonstreres, hvordan "[s]proget afslører platuglerne" (166-67). Denne slagfærdige stil kan i første omgang tjene til at forsikre læseren om, at sproglige emner - og de fagfolk, der formidler dem - ikke behøver at være kedsommelige. Ole Meisner demonstrerer således, at 
han ejer faglig selvironi, men demonstrationen er ikke blot en indledende gestus, der skal vinde læserens velvilje og danne kontrast til en ellers stram fremstilling. Som jeg vil påpege i det følgende, er tekstens struktur og stil som helhed præget af en uoverskuelighed, der forekommer bevidst, fordi den understøtter den humoristiske effekt.

Hvad jeg vil betegne som et humoristisk uoverskuelighedsprincip, er synligt allerede på skimmeniveau. Overskrifter som fx "Flere sjuskefejl" eller den metaforiske "Salver af fejlskud" (mine fremhævelser) giver læseren oplevelsen af, at skribenten deler ud af et bugnende lager af eksempler, og at problemstillingen er (komisk) uafgrænset. Eksemplerne på dårlig sprogbrug får eksplicit lov at knopskyde pr. subjektiv association, når fx en opregning får form af en tolvpunktsliste (162) eller breder sig over hele tre sider, som det er tilfældet med den førnævnte "gabestok" (183-5). Sprogbrugseksemplerne grupperes altså, men det gøres i kategorier, der er subjektivt og upræcist definerede, hvilket frem for alt tjener en humoristisk funktion. Et påfaldende eksempel er førnævnte klassificerende betegnelser "de ulidelige", "de lumske" og "de værste", men mest prominent er hovedkategorien "hadeord". Det er rummelige kategorier med plads til egne og andres videre associationer.

Hvor, som tidligere nævnt, de øvrige kapitler i bogen har fokus på velkendte sproglige kategorier, behandler "Haderen" alle mulige sproglige fænomener, læseren ifølge skribenten ikke bare bør bemærke og undgå, men sammen med sine fagfæller græmme sig over. Det handler især om klicheer, men er ikke begrænset hertil. Der er fokus på enkeltord, der bliver brugt for ofte eller forkert (154-9), indlån fra engelsk og oversættelsesfejl (160-5), markedsføringsjargon ("Hjørring og branding", 166-8), pleonasmer ("Dobbelthederne", 169-71) og formelle fejl ("fejlskud", 172-5). "Kan man hade forkortelser. Ja, da", lyder indledningen til et afsnit om (overfor)brug af forkortelser (176), og der "er mere, man kan se sig gal på", hedder det i et afsnit om tegnsætning, der sætter fokus på bare et enkelt tegn: "Hadetegnet - tankestregen" (181-2). Formelle og mere socialt og kulturelt betingede fejltrin behandles altså side om side, og om et bestemt sprogligt fænomen tages op til behandling, beror på dets vilkårlige dadelværdighed. 
Som det fremgår, udgør selve denne vilkårlighed en essentiel dimension af kapitlets underholdningsværdi, der i ret vid udstrækning synes at være blevet et formål i sig selv. Dertil kommer, at underholdningsaspektet kan distrahere fra den grundholdning, som humoren er betinget af, nemlig en opgivende ærgrelse, der er så stærk, at skribenten vælger at lægge selve sprogfagligheden til side. Den dårlige sprogbrug bliver revset alene på baggrund af irritation: "Det er da ulideligt", hedder det med selvfølgeligt eftertryk om journalisters brug af glosen "danskerne" (155), og en almindelig sluthilsen fremstilles som en indlysende forulempelse: "Tænk alene på det uvenlige $m v h$ (eller m.v.h.)" (179). Den manglende redegørelse eller argumentation for, at fejltrinnet er et fejltrin, signalerer, at den underliggende faglige logik og kvalitetsvurdering er en selvfølgelighed, som læseren forventes at forstå det faglige og sociale grundlag for og dermed dele skribentens intuitive følelser omkring (se også Becker Jensen, 2013: 147).

Selvom der hos Meisner er en gennemgående og klar ironisk kontrast mellem lærebogskonteksten og den uformelt konverserende stil (jf. fx vendingen "Det er da ulideligt"), synes fremstillingen faktisk ikke at betone, at skribenten ikke mener, hvad han skriver. Det kommunikeres, at sprogrevserfunktionen er og bliver lidt af et sisyfosarbejde, fordi de mange anstødssten så at sige bliver ved at komme rullende tilbage på skribentens vej: "[S]ådan går det løs [med brug af glosen "danskerne"] mange gange dagligt" (155), eller: "Blandt forholdsordene er det, der i øjeblikket stikker mest i øjnene, det grasserende på" (174-5, fremhævelse original). Fagligheden opgives så at sige, fordi den tilsyneladende ikke kan hamle op med den virkelighed, den forventes at beskrive og strukturere.

Den samlede holdning, der formidles, kan faktisk betegnes som resignation. Den præsenteres ganske vist med et glimt i øjet, hvilket skribenten fremhæver med en række stilistiske træk: humor og ironi, overdrivelser og strukturel uoverskuelighed eller uafgrænsethed. Men formålet med Meisners ironi synes ikke at være at negere resignationen: Stilen signalerer faktisk, at skribenten ikke har fundet det umagen værd at fremstille sit stof systematisk eller præcist, fordi stoffet, altså opregningen af danske sprogbrugeres og i særdeleshed journalisters uvaner, ikke er 
til at tæmme. Så selvom vi befinder os i en lærebog, hvis hovedfunktion er at ruste sin læser til at skrive godt, synes tekstens fremstillingsform at undergrave sit erklærede ærinde. De utrænede skribenter, der inviteres til at dele ironikerens perspektiv, inviteres nemlig ikke til at dele den faglighed, der ligger til grund for perspektivet, men opfordres på paradoksal vis til at dyrke en ironi og ærgrelse, de samtidig selv - som utrænede, lærende skribenter - står i skudlinjen for.

Denne læsning af Meisners kapitel giver anledning til sammenligning med det amerikanske eksempel, der har nogle slående retoriske træk til fælles med "Haderen", men som samtidig formidler en anderledes grundholdning, der kunne kvalificere skribenten, Stanley Fish, til en modsatrettet, men tilsvarende patospræget titel: "Elskeren".

\section{Stanley Fish og de nydende sprogentusiasters fællesskab}

Stanley Fish (født 1938) er amerikansk litterat og kendt som en aktiv, uhøjtidelig, ofte polemisk deltager i både akademiske og offentlige debatter. Ligesom for Ole Meisner er det oplagt for Fish at vælge en essayistisk stil, der betoner mange års professionel omgang med sproget, og at lade sin holdning til stoffet blive et bærende hovedindhold, når han henvender sig til et alment publikum for at lære dem How to Write a Sentence and How to Read One. Som bogens ligefremme og næsten naivt enkle titel signalerer, har Fish ligesom Meisner besluttet at skrive underholdende og i øjenhøjde med sine læsere.

I indledningen tager Fish eksplicit afstand fra en anden amerikansk bog med titlen Grammar Sucks (Kimes og Muschla, 2007), der med sit tydeligt ironisk-negative udtryk også markerer en holdnings- og underholdningspræget tilgang. Fish karakteriserer fremstillingsformen i Grammar Sucks som fremmedgørende:

With each part of speech comes a list of errors you can, and probably will, make while trying to deploy it; obscurity of reference (what are these things, anyway?) is joined by fear, and the goal of being comfortable with the task of writing recedes into the distance. (14) 
Fish tager afstand fra den uhøjtidelige bog, men det skyldes vel at mærke ikke, at den er uhøjtidelig. Tværtimod appellerer Fish selv til en næsten anti-akademisk holdning til sprog, hvilket $\mathrm{fx}$ afspejles i den ironisk-fremmedgjorte sidebemærkning "(what are these things, anyway?)" Men snarere end at slå et slag for korrekthed a la Meisner betoner Fish fortrolighed med skrivehåndværket (jf. "the goal of being comfortable with the task of writing") og glæden ved velformet sprog i det hele taget.

Et godt eksempel på denne fornøjelse, som afspejler sig $\mathrm{i}$ sproget, er et lille afsnit, der er så markant formet, at det nærmest er blevet bogens varemærke. Det indgår i flapteksten og er ofte citeret i medieomtale af bogen:

Some people are bird watchers, others are celebrity watchers; still others are flora and fauna watchers. I belong to the tribe of sentence watchers. Some appreciate fine art; others appreciate fine wines. I appreciate fine sentences. (3)

Selvom vi ved, at Fish beskæftiger sig professionelt med sproget, fremhæves det i passagen her som en hobby. Ligesom Meisner sætter Fish en ære i opmoerksomhed på sproget, hvilket begge forfattere demonstrerer for læserne i kraft af en koket selvfremstilling, der betoner en form for samlermani i relation til stoffet: Meisner kan ikke lade være med at indsamle og harcelere over de sprogfejl og klicheer, der omgiver os i dagligdagen; Fish kan ikke lade være med at samle på de gode sætninger, han falder over.

"Samlermanien" fungerer som metafor for den faglige etos, læserne skal inddrages i, og manien afspejler sig i den akkumulative, associative stil, der også genkendes fra Meisner. Fish blander højt og lavt og understreger, at de gode sætninger findes allevegne, og at læseren kan finde dem blot ved at holde øjnene åbne. "A good sentence can turn up in the middle of a movie" (4), skriver Fish og fremhæver en replik fra en klassisk westernfilm. Med en bemærkning om, at selv børn kan skrive gode sætninger, følger han op med et eksempel fra en skolestil, som hans svigermor, der er lærer, engang har modtaget (5). På denne vis åbnes der for en "demokratiserende" mangfoldighed af eksempler. ${ }^{7}$ 
Også denne idealisme er et aspekt, Fish har til fælles med Meisner: Alle kan være med. Alle kan på amatørniveau blive vakt til at hade/nyde sproget, der omgiver os, og blive optaget af at indsamle eksempler og dele særligt fine fund. De sprogrevserspalter og -kronikker og især -Facebookgrupper, jeg nævnte indledningsvis, illustrerer tydeligt dette træk: Man samler og deler sine observationer og bygger et socialt fællesskab, inkl. en bestemt holdning og humor, op omkring dem. Fornøjelsen ved at se andre sprogbrugere snuble eller brillere beror i bund og grund på identifikation, idet vi kan nyde, at det ikke er os selv, der snubler, eller ønske, at det var os selv, der brillerede. Og beundring af det brillante er netop, hvad Fish søger at anspore til.

Ypperlige sætninger kan på linje med ypperlige sportspræstationer betragtes, analyseres og beundres som "performances of a certain skill at the highest level", skriver Fish, og det kan vi gøre, alt imens vi kan begræde vores egen manglende evne til at præstere noget lignende (3-4). Sidstnævnte perspektiv kunne måske have givet anledning til resignation, men Fish tager konsekvent udfordringen op. Med en vis ironisk effekt demonstrerer han $\mathrm{fx}$, at han selv kan skrive fermt og rytmisk. Den tidligere citerede passage ("Some people are bird watchers ..." etc.) er et godt eksempel, fordi den på stilniveau udtrykker den sprogglæde, den samtidig handler om. Stilen bliver dermed mimetisk (jf. fx Fish selv, 2011: 58) eller ikonisk (Leff og Sachs, 1990; Jasinski, 2001; Leff, 2003). Det sker især ved brug af stilfiguren gradatio, optrapning, der fremhæver sætningens pointe: Først gentagelsen (tre gange plus én) af glosen "watchers", der skaber kontinuitet og variation; dernæst gentagelsen (tre gange) af den ubetonede formulering "appreciate fine (...)”, der sørger for at fremhæve de betonede sidsteled, der vokser fra en-stavelses- (art, wine) til et tre-stavelsesord (sentences) i retning af et formelt højdepunkt. Her etableres en selvbevidst komisk overraskelseseffekt, et antiklimaks, fordi figuren på indholdssiden faktisk toner ned fra god kunst til gode vine og ender ved en kategori, der umiddelbart kan synes banal, men altså ikke desto mindre fremhæves på sætningens og afsnittets prominente sidsteplads: gode sætninger. Bl.a. på denne måde bringer Fish sig (ned) i øjenhøjde med læseren, men sætter samtidig et stilistisk eksempel, som læseren kan nyde. 
Fish betegner selv bogens formål som "at once aesthetic and practical ... I promise to give you both sentence pleasure and sentence craft, the ability to appreciate a good sentence and the ability to fashion one" (8). Han vil demonstrere, hvordan fortrolighed med form kan give læseren beredskabet til at formulere sig slående, når anledninger (sidenhen) opstår. Fortroligheden opnås ved at beundre virtuose sætninger, aflure deres mønstre og selv lege videre med former og udtryksmuligheder.

Denne ambition om at engagere og aktivere læseren stiller krav også til strukturen på Fishs egen prosa. I vid udstrækning synes han på strukturniveau at undvige den faldgrube, der følger med den akkumulative stil, jeg beskrev hos Meisner, hvor eksemplerne hober sig op. Ganske vist, som vi så før, dyrker også Fish det akkumulative, men det sker primært i indledningskapitlet som en måde at underholde og mobilisere læserne på. Eksempelopregningen fortsætter ganske vist, men den følges op af detaljerede diskussioner af eksemplerne, og den foretages med henvisning til tre hovedkategorier af sætninger: den underordnende, den sideordnende og den satiriske, som tildeles hver deres kapitel. Læserne kan lære at genkende disse formater, de opfordres til at øve sig på dem og får også demonstreret hvordan (se fx 23-24). Så alt imens det klart formidles, at eksemplerne er utallige og mangfoldige, tilbyder bogen faktisk en overskuelig og funktionel grundstruktur, der er fagligt motiveret, hvilket, som vi har set, ikke er nogen selvfølge i denne type inspirationstekster, den essayistiske håndbogslitteratur.

Som læseren måske bemærkede, brugte jeg ovenfor Fish som reference til den mimetiske stil, han selv praktiserer. Han bruger bl.a. en sætning fra John Miltons An Apology Against a Pamphlet som et skoleeksempel på "mimetic form ... words [that] do what they describe" (58). Denne sans for form, der understøtter eller ikke understøtter et konkret indhold, er også, hvad Meisner efterspørger, når han (med reference til Erik Hansen) betegner de forhadte klicheer, han indsamler, som "mislykkede overraskelser", fejlslagne forsøg på at være kreativ. Men ser vi på Meisners og Fishs tekster, så er det faktisk kun Fishs, der på det stilistiske niveau gør, hvad begge tekster siger, de gør: værdsætter selvstændig sprogbrug. Meisners stil er også mimetisk, men den 
intention, den mimer og realiserer, er den ironisk formulerede intention. Teksten realiserer et negativt modstykke til den værdi, den egentlig ønskede at styrke. Det er en overraskelse, men en triviel eller bare konventionel og i den forstand mislykket overraskelse: en kliché.

\section{Stærke stemmer sætter ikke altid et godt eksempel}

I denne sammenlignende analyse af Meisner og Fishs skrivepædagogiske essayistik har jeg påpeget, hvilke socialiserende mekanismer der er i funktion i den type retorik, der på godt og ondt vil danne sit publikum som bevidste sprogbrugere ved en uhøjtidelig og slagfærdig henvendelsesform. Retorik af denne karakter kan samle og motivere, begejstre og engagere, og i den offentlige og semioffentlige sprogdebat kan den ofte findes i de to modsatrettede former, jeg har peget på: Man samles om at dele og beundre eksempler på god sprogbrug, eller man samles om at dele og ironisere over eksempler på dårlig sprogbrug. Specielt sidstnævnte, sprogrevsende humor, hvor man anekdotisk deler sine observationer af "bøffer", "rædsler", "hadeord" eller "kvajerier" (der kan være resultatet af alt fra sjusk over opblæsthed til uvidenhed og kan rumme alt fra klicheer og idiomatiske misforståelser til grammatiske fejl), er udbredt og umiddelbart genkendelig. Men netop fordi den synes relativt ukontroversiel i vores kultur, kræver den vores kritiske opmærksomhed.

Et citat fra et af de nævnte sprogrevser-debatindlæg fra dagspressen synes på én gang at formulere og demonstrere problematikken i en nøddeskal, og jeg bringer derfor et længere citat. Det er forfatterne Mich Vraa og Susanne Staun, der i en kronik i Politiken med påfaldende stærk stemme ("Lær det nu bare ...", 8/11 2012) skriver:

Sidste vinter, hvor vi pludselig opdagede, at vi ikke længere var $i$ stand til at læse avis eller høre nyheder uden at græmme os i bund over de makabre sprogfejl, vi dér blev ramt af i byger, faldt det os naturligt at oprette en sprogblog, Mich\&Susse, hvis formål var hver uge at præstere en "peptalk for sprogsinker, wannabe pedanter og alle, der bare ønsker at være lidt lækrere» eller sagt med andre 
ord: gøre det street at tale og skrive på en begavet måde, der gør sproget til en del af det udstyr, man tager på, når man gerne vil være lidt lækker.

Indtil videre er det kun lykkedes os at blive kult hos de andre pedanter, men vi vil så gerne have fat i nakken på analfabeterne: Disse mærkelige, sprogbedøvede mennesker, der altid fortæller os, at vi burde få os et liv, en anbefaling, der ofte ledsages af et par bandeord, de ikke kan stave til.

Afsnittet synes at demonstrere den faldgrube, Vraa og Staun selv peger på, hvor skribenterne rituelt underholder de indviede (i "kulten") snarere end at række ud til de mennesker, de angiver at ville nå for at skabe forandring. Den veletablerede sprogrevserdiskurs, der tillader Vraa og Staun at omtale svagere sprogbrugere som sinker, der skal tages i nakken, er gennemført ironisk, idet de to stærkere sprogbrugere, der fører pennen og demonstrativt besidder de sproglige kompetencer, de efterspørger, tillader sig at posere som den konstant krænkede part (der fx rammes af makabre fejl $i$ byger).

Det kan undre, at de gammeldags termer "røgte" og "revse" fortsat er helt gængse i relation til sproglig korrekthed, når det ikke er tilfældet på andre områder: Man røgter ikke længere sine fattige og syge eller sine dyr og marker, og man revser ikke længere sine elever (ligesom man heller ikke kan forsvare at kalde dem fx sinker eller spassere). Men man kan fortsat uden videre påtage sig rollen som sprogrøgter eller sprogrevser (og i spøg irettesætte verdens sprogsinker eller sprogspassere) og endda lade de gammeldags betegnelser kaste et forsonende, komisk skær over ens praksis. I kraft af disse termer bliver rollen i sit udgangspunkt vinklet som gammeldags "skolemesteragtig" og næsten pr. definition indskrænket eller i al fald pædagogisk utidssvarende. Netop derfor kan det også virke relativt trivielt, når skribenter og debattører tager afstand fra rollen med selvironi, fx ved at overspille og (over)kompensere med humor og ironi. Min analyse skal gerne give anledning til at overveje, i hvilke kontekster humoren hører hjemme, og hvilke funktioner den tjener: Hvornår er det faktisk rimeligt at forudsæette, at ofret (der begår latterlige sprogfejl) og modtageren (der inviteres til at grine) burde vide bedre? At det sker i håndbøger, der decideret er henvendt til 
urutinerede skribenter (der formentlig begår latterlige sprogfejl og alligevel inviteres til at grine) er tegn på, at formen er i færd med at stivne. Den kommer til at demonstrere alt andet end den sproglige situationsfornemmelse, den søger at fremelske. ${ }^{8}$

At efterligning, som Fish anbefaler det, i stedet skulle være en farbar vej til at undvige lige præcis klichepræget sprog, kan umiddelbart lyde paradoksalt. Fx Robert Terrill (2011) argumenterer imidlertid for, at det at nærlæse andres ord i kontekst og derefter eksperimentere med at tage bestemte træk i anvendelse i nye kontekster netop kan øge studerendes sans for, hvordan sprog fungerer i konkrete situationer, og hvordan tekster forholder sig til hinanden på tværs af situationer. Det sidste kan skærpe bevidstheden om ens eget sproglige råderum i relation til andres, hvilket synes indlysende værdifuldt for eksempelvis journaliststuderende, der skal udvikle et reflekteret forhold til tekstkvalitet i kildemateriale af alle typer, og som skal forholde sig til altid aktuelle og problematiske fænomener som sproglig afsmitning og plagiering. At belyse og evaluere selve denne selektive, kreative efterligningspraksis som pædagogisk princip vil kræve (inddragelse af) helt andre typer undersøgelser foruden en yderligere tilpasning til den journalistikfaglige kontekst. Det levner rammerne for denne artikel ikke plads til.

Jeg håber til gengæld, at jeg med læsningen af de to markante eksempler har udfoldet og nuanceret forståelsen af den kategori, Bech-Karlsen betegnede som "inspirationstekster" inden for skrivelitteraturen. I den essayistiske håndbogslitteratur kan skribenter med stærke stemmer motivere og engagere læseren fagligt ved at tilbyde en uhøjtidelig stund, hvor den stærke stemme bliver demonstreret for læseren og skærpet i relation til stoffet. Jeg håber endvidere at have sandsynliggjort, at der er klart forskelligt pædagogisk potentiale i de to konkrete grundholdninger, jeg har belyst. Skribentautoriteter kan lægge op til at samle og dele eksempler på ufrivilligt komisk sprogbrug, der skal bemærkes for at undgå gentagelse eller afsmitning, eller de kan sætte læseren i gang med at opsøge gode eksempler, hvis kunst tværtimod gerne kan gøres efter. Hvor "haderens" holdning forekommer at være langt den mest underholdende, forekommer "elskerens" at være holdbar og langt mere lærerig for læseren. 


\section{REFERENCER}

Andersen, Øivind (1995). "Retorikk, pedagogikk og kultur”, I retorikkens hage. Oslo: Universitetsforlaget: 217-272.

Bech-Karlsen, Jo (1998): Jeg skriver, altså er jeg: En bok for fagskriveren som vil fortelle. Oslo: Tano Aschehoug.

Becker Jensen, Leif (2013). ”Den journalistiske automatskrift - når sproglige normer bliver til sproglige dogmer", Journalistica 1: 141-171.

Elbow, Peter (2007). "Voice in Writing Again: Embracing Contraries". English Department Faculty Series. Paper 7. University of Massachusetts, Amherst: http://scholarworks.umass.edu/cgi/viewcontent. cgi?article=1006\&context=eng_faculty_pubs (besøgt 23.01.2013).

Fish, Stanley (2011): How to Write a Sentence and How to Read One. New York: Harper.

Harsting, Pernille (2001). Indledning til Quintilian, En talers uddannelse X.2. Aigis 2. http://aigis.igl.ku.dk/2001,2/Harst.Quint.indl.pdf (besøgt d. 26.10.2013).

Hart, Roderick (1997). Modern Rhetorical Criticism. Boston: Allyn \& Bacon.

Hartling, Anna Sofie (2012). "Grineren - og andre grineren ord. En grammatisk statusopgørelse." Nyt fra Sprognoevnet 1: 1-6.

Hoff-Clausen, Elisabeth (2008): Online Ethos. Webretorik i politiske kampagner, blogs og wikis. København, Samfundslitteratur.

Isager, Christine, og Anders Sigrell (red.) (2015): Rhetorica Scandinavica 70: Tema: Imitatio. Under udgivelse.

Jasinski, James (2001): “Iconicity”, Sourcebook on Rhetoric. Key Concepts in Contemporary Rhetorical Studies. Thousand Oaks: Sage, 303-5.

Kimes, Joanne, og Gary R. Muschla (2007): Grammar Sucks: What to Do to Make Your Writing Much More Better. Avon, MA: Adams.

Kock, Christian (2007): "Sproglig kvalitet”, i: Vibeke Sandersen \& Jørgen Schack (udg.): Dansk Sprognoevn - godt og vel 50 år efter. København: Dansk Sprognævn, 53-73.

Kock, Christian (2013): "Imitatio: en bro mellem tekstlæsning og skriftlig fremstilling”. Retorisk praksis. Ödåkra: Retorikforlaget: 103-12.

Leff, Michael, og Andrew Sachs (1990): "Words the Most Like Things: Iconicity and the Rhetorical Text”. Western Journal of Speech Communication 54: 252-73.

Leff, Michael (2003). ”Fortolkende retorisk kritik”. Oversat af Lisa Storm Villadsen. Rhetorica Scandinavica 26: 6-19.

Lund, Marie, og Hanne Roer (red.) (2014). Retorikkens aktualitet. Grund- 
bog i retorisk kritik. 3. udg. København: Hans Reitzels Forlag.

Meisner, Ole (2004). "Haderen”. Odense: DR og Syddansk Universitetsforlag.

Quintilianus, Marcus Fabius (2001). ”Om efterligning og om originalitet" (En talers udannelse X.2). http://aigis.igl.ku.dk/2001,2/Harst. Quint.overs.pdf (besøgt 26.10.2013).

Skyum-Nielsen, Peder (red.) (2008). Godt dansk. Med kapitler af Ebbe Grunwald og Ole Meisner. Odense: Syddansk Universitetsforlag/DR.

Terrill, Roger (2011). "Mimesis, Duality, and Rhetorical Education,” i: Rhetoric Society Quarterly, 41.4: 295-315.

Villadsen, Lisa (2009): ”Retorisk kritik," i Charlotte Jørgensen og Lisa Villadsen (red.): Retorik: Teori og praksis. København: Samfundslitteratur: 195-218.

\section{NOTER}

1 blog.politiken.dk/?p_o=150, besøgt 21.6.2013.

2 Mads Zacho Teglskov: "Afstemning: Hvilket ord er sprogets allerækleste?" Politiken 12.1.2014; "'Vækste' er det danske sprogs allerækleste ord", Politiken 20.1.2014.

3 Se fx Karsten Bräuner: "Elitens elizaficering af det danske sprog", Berlingske 19.8.2012. Bent Hvorslev: "Vort Modersmaal er dejligt ...", Jyllands-Posten, 26.12.2012.

4 https://www.facebook.com/groups/6766351133/?fref=ts (6.552 medlemmer pr. 27.1.2014); https://www.facebook.com/ sprogpolitiet?fref=ts (25.128 digitale "Synes godt om"-tilkendegivelser pr. 27.1.2014); https://www.facebook.com/DagensSprogsinke?fref=ts (1.612 medlemmer pr. 27.1.2014).

5 Referencerne i citatet er til følgende kilder: Vibeke Sandersen (1975): Essayet - oprør og tradition. København: Gyldendal; Ottar Grepstad (1997): Det littercere skattkammer - sakprosaens teori og retorikk. Oslo: Samlaget; Vivian Greene-Gantzberg \& Phillip Marshall Mitchell (1997): Den fjerde genre. Essayet i Danmark. København: C. A. Reitzel.

6 Jørn Lunds motivering for tildelingen af Danmarks Radios sprogpris til Ole Meisner i 1990 kan læses her: http://sproget.dk/raad-og-regler/artikler-mv/sprogbrevet-dr/sprogbrevetdr-nr-54/sprogprisen, besøgt 27.1.2014. Bemærk i øvrigt, at Lund her fremhæver sprogprisen i sig selv som en fejring af det gode eksempel i kontrast til Sprogbrevet DR (udgivet af Jørn Lund og Erik Hansen i perioden 1985-1995), som 
ellers typisk, siger han, "kom (...) til at handle om fejl og mangler".

7 Et udvalgt anmeldelsescitat på bogens omslag: "Both deeper and more democratic than The Elements of Style" (Adam Haslett, Financial Times)" giver udtryk for, at dette er et vigtigt aspekt af bogens varemærke.

8 Susanne Staun har sidenhen udgivet Fuck(,) en loekker røv: Basisgarderobe til den nøgne sprogbruger (København: Gyldendal, 2015), der varierer formatet ved at skrive ikke $\mathrm{om}$, men personligt og direkte til "selv den splitternøgne sprogspasser. Er det dig? [... D]ig, der hver dag dummer dig, når du skriver, men også når du taler, og oftest uden at vide det" (6-7). 